\title{
FROM THE HISTORY OF TOLERANCE PRINCIPLE IN UZBEKISTAN
}

\author{
Ergashev Ravshanbek Rasulovich \\ Senior teacher at the department National idea, bases of morality and law education of \\ Andizhan State University, Andizhan, Republic of Uzbekistan
}

Article DOI: https://doi.org/10.36713/epra1225

\begin{abstract}
The given article analyzes religious tolerance and the revival of Islamic traditions in Uzbekistan using regulatory and scientific literatures and sources as well. It has also analyzed that in our independent republic the issue of harmony, peace and harmony among nations is of great importance, and tolerance has always been a behavioral goal in all historical periods.
\end{abstract}

KEY WORDS: Uzbekistan, religious tolerance, spiritual values, confession, interethnic consent, religious organization, constitution, freedom of conscience.

\section{INTRODUCTION}

To begin with since Uzbekistan gained independence, the concept of interethnic harmony and religious tolerance has played an important role in the life of society. In particular, on the initiative of the President of the Republic of Uzbekistan Sh.Mirziyoev Strategy of Action on five priority directions of development of the Republic of Uzbekistan for 2017-2021 is developed. Its fifth focus is on "Ensuring security, interethnic harmony and religious tolerance, as well as priority areas in a well thought out, mutually beneficial and practical foreign policy" [1, p.45]. In our independent republic, the issue of harmony, peace and harmony among nations has played an important role. It is well known that, in all historical periods, tolerance has always been a behavioral goal. At the same time, the deep social changes taking place in the context of independent development in our country have accelerated the process of building a new national statehood in the mentality of Uzbeks. Not only that, tolerance, which is one of the most basic democratic principles, is growing not only at the state level, but also at the level of individuals and groups. Tolerance also means respect for the lifestyle, character, feelings, ideas, ideas and religious views of people of different ethnic groups. The aim of the study of the formation of a new system of interethnic relations is to provide a holistic and complete picture of the state of such relations among all social groups, especially young people.

\section{METHODS}

The concept of "tolerance" is used in various fields of scientific activity and social life, including political and political science, sociology, philosophy, theology, social ethics, comparative theology [2, p.25]. It is clear that the importance of tolerance is given to the fact that many international events have been launched to draw the attention of the world community to this vital issue, including the United Nations in 1995 devoted direct tolerance. These activities seek to create conditions conducive to the development of tolerance, with efforts to address the factors that hinder the solution. One of such factors is the globalization of the modern world.

The essence of the process of globalization is that the interconnectedness and interdependence of both people and states is greatly enhanced and complicated. There is a global information market, a global market of capital, goods and labor forces, and the problem of anthropogenic impact on the environment, interethnic and interreligious conflicts, and global security. The process of globalization of the modern world reminds mankind that the world is diverse and at the same time unique. Because of the diversity of cultures, approaches to the same processes are different, but this can be a threat to certain social entities and the world at large [3, p.18]. 


\section{EPRA International Journal of Research and Development (IJRD)}

In this process, the interconnectedness of the human being is strengthened, and the responsibility for its future destiny is undoubtedly the key to the formation of a culture of tolerance. Economic interdependence, globalization of information and interdependence in terms of security are the hallmarks of today's globalization. Tolerance - not passive dependence on the opinions, opinions and actions of others; it is an active spiritual position, not an obedient patience; mental readiness for tolerance for interethnic, social, or positive interactions with people of other cultural, national, religious, or social environments $[3$, p.20].

\section{RESULTS AND DISCUSSIONS}

Article II of the Constitution of the Republic of Uzbekistan states that "all citizens of the Republic of Uzbekistan, regardless of their nationality, are the citizens of the Republic of Uzbekistan" Article V states: "All citizens of the Republic of Uzbekistan have the same rights and freedoms, sex, race, nationality, language are equal before the law, irrespective of their religion, social origin, beliefs, personality or social status. Privileges should be established only by law and must conform to the principles of social justice "'[4, p.16].

The principle of national equality of Uzbek citizens fully complies with all international human rights instruments, including the Paris Charter for New Europe, signed by the President on behalf of the Republic of Uzbekistan [5]. This principle serves as a legal guarantee of peace, political stability and interethnic harmony in our country.

The history of independent development of Uzbekistan coincides with the new century, with the end of the century, when the interethnic and interreligious enmity in the world has grown. In our eyes, all countries are destroyed because of the conflict of national interests in those countries. That is why when we say that Uzbekistan's greatest achievement is interethnic harmony and harmony, peace and stability, this is not only a well-known fact, but also a great success of the current turbulent republic. There are many causes of ethnic conflict in the world, and many of these are caused by three major problems:

1. Globalization expands peoples' cooperation, enables all societies to enjoy the latest technological advances, radically transforms economic structures, makes the world a unified communication system, while losing many of its historical roots - national identity, language, cultural and religious traditions. There is a natural concern about these feelings, which sometimes provokes opposition to other ethnic and religious values.

2. As a result of globalization, internal tensions in some national states are exacerbated, state boundaries are vanishing, and through these borders not only the benefits of civilization, but also many global threats [3, p.22].

Tolerance, that is, tolerance, plays an important role in the conscious life of the person and in the mentality of the society, creating new consciousness and awareness. The modern concept of tolerance has recently emerged, and UNESCO has put much effort into developing this concept. In particular, in the "Declaration of Tolerance Principles" adopted by this organization in 1995 , tolerance was defined as the value and social norm of civil society [3, p.19].

Taking into account the experience gained over the years, in 2000 a permanent seminar on "Solidarity and Tolerance - a Guarantee of Development" was opened. This workshop is dedicated to the efforts of all nationalities and ethnic groups living in the Republic to work together to build a more prosperous and prosperous society. As part of the seminar, scientific and cultural conferences and other events dedicated to the 559th birthday of Alisher Navoi were held in Tashkent. Travel seminars were also held in Khorezm, Andizhan regions and the Republic of Karakalpakstan [6].

In independent Uzbekistan, the heads of state bodies and religious organizations have established mutual understanding and goodwill. On July 14, 1991, the Law on Freedom of Conscience and Religious Organizations was adopted for the first time in Uzbekistan's legal practice. After the adoption of the Constitution of the Republic of Uzbekistan freedom of conscience, relations between the state and religion are regulated by constitutional principles. On May 1, 1998 a new version of the Law on Freedom of Conscience and Religious Organizations was adopted.

March 27, 1992 The Decree of the President of the Republic of Uzbekistan "On the announcement of the first days of fasting and Eid al-Adha as a day of rest" was signed. In accordance with the Decree of the President of Uzbekistan dated June 2, 1990 "Muslims to Haj in Saudi Arabia", for the first time in the history of the people of Uzbekistan, the government has the opportunity to perform Haj and Umrah directly under the auspices of the government. During the years of independence, more than 32,000 Uzbeks traveled to Mecca and Medina. Hundreds of mosques were returned to Muslims and new ones were built. The Islamic Nuri newspaper is published. These events are not just a blessing for the believers, they are a revival of the ancient customs of our people - customs and traditions, values, revival of ancestral spirit.

As stated in our Basic Law, "Freedom of conscience is guaranteed to all. Everyone shall have the right to profess or not to profess any religion. No compulsory imposition of religion shall be permitted" 


\section{EPRA International Journal of Research and Development (IJRD)}

[4, p.8]. It also states in the Law on Freedom of Conscience and Religious Organizations that citizens of Uzbekistan are equal before the law, regardless of religion" [7, p.225]. These laws are up to date and guarantee the right of citizens to practice their religion freely and to practice religious customs.

\section{CONCLUSION}

During the brief but honorable years of independence a number of reforms have been implemented in the judicial system of the country. Of course, every existing law is aimed at protecting human rights and the rights of all citizens. During the years of independence, the Constitution of the Republic of Uzbekistan and the Law on Freedom of Conscience and Religious Organizations have been adopted, guaranteeing the freedom of conscience of all citizens residing in the country.

\section{REFERENCES}

1. Decree of the President of the Republic of Uzbekistan Sh.Mirziyoev dated February 7, 2017 $P D-4947$ "On the strategy of further development of the Republic of Uzbekistan" // Collection of legislation of the Republic of Uzbekistan.-№6 (766). - Tashkent: Adolat, 2017.

2. Scientific-methodical brochure on the study of the State Program on implementation of the Strategy of Action on the five priority directions of development of the Republic of Uzbekistan in 2017-2021 in the Year of Dialogue with the People and Human Interests.-Tashkent: Spirituality, 2017.-p.210.

3. Murtazaeva R.Kh. Interethnic relations and tolerance in Uzbekistan. -Tashkent: University, 2007.

4. The Constitution of the Republic of Uzbekistan. Tashkent: Uzbekistan, 2014.-P.12.

5. The New History of Uzbekistan. History of independent Uzbekistan.-Tashkent: Shark, 2000. -p.241.

6. Uzbekistan - Our Common Home // edit. M. Nurmatova. -Tashkent: Uzbekistan, 2001.-P.47.

7. On Freedom of Conscience and Religious Organizations (new edition). New laws of Uzbekistan. - Tashkent: Adolat, 1998. 